\title{
Penerapan Algoritma Neural Network Untuk Klasifikasi Kardiotokografi
}

\author{
Yudi Ramdhani ${ }^{1}$, Sari Susanti ${ }^{2}$, Miftah Farid Adiwisastra $^{3}$, Salman Topiq ${ }^{4}$ \\ ${ }^{1}$ Universitas BSI \\ email: yudi.yrm@bsi.ac.id \\ ${ }^{2}$ Universitas BSI \\ email: sari.srq@bsi.ac.id \\ ${ }^{3}$ Universitas BSI \\ email: miftah.mow@bsi.ac.id \\ ${ }^{4}$ Universitas BSI \\ email: salman.ssc@bsi.ac.id
}

\begin{abstract}
Abstrak
Kardiotokografi adalah metode investigasi yang paling disukai, dalam pemerhati penggunaan kesejahteraan janin yang praktis. Informasi yang diperoleh dari kardiotokografi, digunakan untuk mengidentifikasi awal keadaan patologis (gangguan pada janin, perkembangan penyakit pada janin atau hipoksia dan lain-lain). Organisasi Kesehatan Dunia atau WHO (World Health Organization) memperkirakan sekitar $15 \%$ dari seluruh wanita hamil akan berkembang menjadi komplikasi yang berkaitan dengan kehamilannya dan dapat mengakibatkan kematian ibu dan janin. Teknologi data mining merupakan salah satu alat bantu untuk mengoptimalkan data pada basis data yang berukuran besar, Data mining medis memiliki potensi besar untuk dipelajari pola-pola yang tersembunyi dalam kumpulan data utama medis. Dataset Kardiotokografi memiliki fitur/atribut sebanyak 36 dan diklasifikasikan menjadi 3 kelas yaitu : kelas Normal, kelas Suspect, dan kelas Pathologic dengan record sebanyak 2126. Metode Neural network dapat mengklasifikasi kardiotokografi dengan baik dibuktikan dengan nilai akurasi yang tinggi yaitu sebesar 99,15\%, serta dapat membantu user untuk mengambil keputusan selanjutnya pada Karditokografi tersebut.
\end{abstract}

Kata kunci: Kardiotokografi, Data Mining, Neural network

\begin{abstract}
Absract
Kardiotokografi is the most preferred method of investigation, in the use of fetal well being observers. Information obtained from kardiotokografi, used to identify the initial state of the pathological (disorders of the fetus, the development of fetal disease or hypoxia and others). World Health Organization estimates approximately $15 \%$ of all pregnant women will develop into complications related to her pregnancy and can lead to the death of the mother and the fetus. The technology of data mining is one of the tools for optimizing the data in the data base of large-sized medical. Data mining, has great potential to learn the patterns that are hidden in the main medical data sets. Kardiotokografi DataSet features/attributes as much as 36 and are classified into three classes as follows: Normal class, class Suspect and Pathologic class with the record as much as 2126. Neural network method of classifying kardiotokografi can properly evidenced by high accuracy value of 99,15\%, and can help the user to take decisions on the Karditokografi.
\end{abstract}

Keywords: Kardiotokografi, Data Mining, Neural network 


\section{Pendahuluan}

Kardiotokografi adalah metode investigasi yang paling disukai, dalam pemerhati penggunaan kesejahteraan janin yang praktis. Informasi yang diperoleh dari kardiotokografi, digunakan untuk mengidentifikasi awal keadaan patologis (gangguan pada janin, perkembangan penyakit pada janin atau hipoksia dan lainlain) dan kardiotokografi ini dapat membantu dokter kandungan untuk mengantisipasi masa depan janin sebelum ada gangguan permanen pada janin. Perkembangan janin yang terkena hipoksia dapat menyebabkan kecacatan sementara bahkan tidak tepatnya diagnosis dan perawatan yang diterapkan pada janin dapat menyebabkan kematian pada janin tersebut (Sahin \& Subasi, 2015).

Pemantauan kesejahteraan janin (PKJ) merupakan hal penting dalam pengawasan janin saat asuhan antenatal dan pada saat persalinan. Persiapan pra konsepsi yang baik akan memengaruhi kesejahteraan janin (Endjun \& Affandi, 2013). Organisasi Kesehatan Dunia atau WHO (World Health Organization) memperkirakan sekitar 15\% dari seluruh wanita hamil akan berkembang menjadi komplikasi yang berkaitan dengan kehamilannya dan dapat mengakibatkan kematian ibu dan janin. Data Provinsi Sulawesi Utara tahun 2012 sasaran ibu hamil 47,503 dan untuk pencapaian $\mathrm{K} 1$ berjumlah $14.259 \quad(27,6 \%), \quad K 4$ berjumlah 15.271 $(35,7 \%)$, sedangkan data yang didapat tentang Angka Kematian lbu (AKI) yang meninggal adalah $49(0,10 \%)$ dengan penyebab yaitu perdarahan (36\%), eclampsia (29\%), infeksi (4\%) dan yang lain-lain (29\%) (Dinkes Sulut, 2013).

Data mining adalah proses menemukan hubungandalam data yang tidak diketahui oleh pengguna dan menyajikannya dengan cara yang dapat dipahami sehingga hubungan tersebut dapat menjadi dasar pengambilan keputusan (Yulianto \& Fitriati, 2008). Teknik data mining yang akan digunakan dalam penelitian ini adalah algoritma NBC yang merupakan sebuah pengklasifikasi probabilitas sederhana yang mengaplikasikan Teorema Bayes. Ide dasar dari Teorema Bayes adalah menangani masalah yang bersifat hipotesis yakni mendesain suatu klasifikasi untuk memisahkan objek (Santosa, 2007).

Teknologi data mining merupakan salah satu alat bantu untuk mengoptimalkan data pada basis data yang berukuran besar, dengan spesifikasi tingkat kerumitan yang telah banyak digunakan pada banyak aplikasi utama seperti perbankan maupun bidang telekomunikasi (Mohammad, 2012). Data mining medis memiliki potensi besar untuk dipelajari pola-pola yang tersembunyi dalam kumpulan data utama medis. Pola atau data tersebut dapat digunakan untuk diagnosis klinis. Data ini dikumpulkan kemudian dapat terintegrasi untuk membentuk sebuah sistem informasi rumah sakit. Teknologi data mining menyediakan pendekatan yang berorientasi user-oriented untuk penelitian dan pola-pola yang tersembunyi dalam data (Soni, Ansari, Sharma, \& Soni, 2011).

Neural network adalah salah satu dari banyak alat analisis data mining yang dapat dimanfaatkan untuk membuat prediksi data medis. Salah satu metode optimasi umum digunakan seperti Genetic Algorithms (GAs), Particle Swarm Optimization (PSO), Ant Colony Optimization (Karegowda, Manjunath, \& Jayaram, 2011).

Dalam penelitian ini klasifikasi Kardiotokografi menggunakan algoritma klasifikasi Neural network dengan menggunakan dataset Kardiotokografi sebanyak 2126.

\section{Metode Penelitian \\ Penelitian Terkait}

Metode neural network memiliki kinerja yang baik dalam mengatasi masalah data nonlinear, namun neural network memiliki keterbatasan dalam mengatasi data noise yang tinggi. Untuk menyelesaikan masalah tersebut diperlukan metode bagging untuk mengurangi data noise pada metode neural network. Beberapa eksperimen dilakukan untuk mendapatkan arsitektur yang optimal dan menghasilkan estimasi yang akurat. Hasil eksperiman dari delapan kombinasi parameter penelitian pada dataset concrete compressive strength dengan neural network didapatkan nilai rata-rata RMSE adalah 0,069 dan nilai RMSE terkecil adalah 0,057, sedangkan dengan menggunakan neural network dan bagging didapatkan nilai ratarata RMSE adalah 0,062 dan nilai RMSE terkecil adalah 0,055.

Hasil eksperimen dari delapan kombinasi parameter penelitian pada dataset slump dengan neural network didapatkan nilai ratarata RMSE adalah 0,020 dan nilai RMSE terkecil adalah 0,011 sedangkan dengan neural network dan bagging didapatkan nilai rata-rata RMSE adalah 0,016 dan nilai RMSE terkecil adalah 0,010. Maka dapat disimpulkan estimasi kuat tekan beton dengan 
menggunakan metode bagging dan neural network lebih akurat dibanding dengan metode individual neural network (Setiyorini, 2015).

Neural network dan Particle Swarm Optimization, Jaringan saraf tiruan (Artificial Neural network) sebagian besar telah cukup handal dalam pemecahan masalah peramalan yang sering ditemukan dalam proses pengambilan keputusan salah satunya adalah prediksi kelulusan mahasiswa dengan menggunakan metode backpropagation neural network. namun proses pembelajaran backpropagation terkadang menemui kendala seperti over fitting sehingga tidak dapat menggeneralisasikan masalah.

Untuk mengatasi masalah tersebut diusulkan penggunaan Particle Swarm Optimization untuk melatih bobot pada jaringan. Variabel input yang digunakan dalam Prediksi kelulusan mahasiswa ini menggunakan yaitu 30 nilai mata kuliah. Output yang dihasilkan adalah kelulusan tepat waktu atau melebihi batas waktu. Adapun tools yang digunakan yaitu MatlabR2010a. Pengujian dilakukan menggunakan perangkat lunak matlab yang diuji dengan beberapa bentuk arsitektur jaringan. Berdasarkan data uji aristektur dengan konfigurasi terbaik untuk $\mathrm{NN}$ terdiri dari 30 lapisan masukan, 25 lapisan tersembunyi dan 1 lapisan keluaran dengan nilai learning rate 0.2 , RMSE 0.070 dengan akurasi $78.26 \%$. Nilai RMSE setelah dioptimasi yaitu 0.048 dengan tingkat akurasi 87.31\% (Kusumawati, Winarno, \& Arief, 2015).

Penilaian kualitas daun tembakau ini terdiri dari dua faktor yaitu human sensory dan human vision yang dilakukan oleh grader. Perkembangan teknologi informasi saat ini mampu melakukan pengolahan citra sehingga dapat memaksimalkan faktor human vision yang diharapkan dapat menghemat waktu dan biaya. Pada penelitian ini, deteksi kualitas daun tembakau didasarkan pada dua ekstraksi fitur daun tembakau yaitu bentuk dan tekstur. Kedua fitur tersebut nantinya akan diklasifikasikan menggunakan optimasi Conjugate Gradient pada Backpropagation Neural network.

Hasilnya, metode yang digunakan mampu meningkatkan tingkat akurasi deteksi kualitas daun tembakau. Peningkatan akurasi untuk klasifikasi grade daun tembakau dengan metode backpropagation neural network mencapai akurasi hingga 77,50\% (Sari, Marleny, Izzana, Ricardus , \& Lareno, 2015).
Neural network banyak digunakan untuk proses klasifikasi, namun proses pelatihan dengan algoritma back-propagation (BP) yang menggunakan metode gradient steepest descent solusinya banyak terjebak kedalam minimum lokal. Tujuan penelitian untuk melakukan optimalisasi dalam proses penentuan pembobotan dari metode neural network dalam mengklasifikasikan aktivitas mental sinyal EEG.

Particle Swarm Optimization digunakan untuk mengoptimalisasi bobot dari NN dengan Evolutionary Direction Operator dan Migration serta menggunakan Fuzzy Inference System untuk menentukan bobot inersia adaptif serta Cross-Mutated Operation merupakan strategi baru yang diusulkan.Metode ini menyediakan peningkatan akurasi untuk tiga pekerjaan aktivitas mental dimana rata-rata akurasi untuk subjek pertama adalah $54,20 \%$, subjek dua $58,40 \%$ dan $54,48 \%$ untuk subjek tiga. Akurasi terbaik dari seluruh percobaan pada subjek pertama adalah $69,18 \%$, subjek dua $67,20 \%$ dan $57,67 \%$ untuk subjek tiga (Sakur \& Tjandrasa, 2016).

Peningkatan jumlah kendaraan bermotor yang terus terjadi di Indonesia tiap tahunnya, membuat kebutuhan akan sistem yang mampu mengidentifikasi kendaraan secara otomatis atau sering disebut Sistem Lalu Lintas Cerdas juga ikut meningkat. Sistem ini dapat digunakan antara lain untuk menemukan kendaraan yang dicuri, pembayaran tiket parkir otomatis, dan menindak para pelanggar lampu merah. Kemampuan utama dari sistem tersebut adalah pengenalan plat nomor.

Pada penelitian kali ini akan digunakan metode Momentum Backpropagation Neural network untuk mengenali karakter dari suatu citra plat nomor kendaraan di Indonesia. Namun sebelumnya, citra plat nomor akan diubah menjadi citra biner. Citra biner kemudian disegmentasi untuk mengisolasi karakter-karakter yang akan dikenali. Terakhir dimensi citra hasil segmentasi akan direduksi menggunakan Haar Wavelet.Uji coba pada penelitian kali ini melibatkan 276 karakter yang terdiri dari huruf dan angka pada plat nomor kendaraan di Indonesia. Hasil uji coba menunjukkan 268 karakter diantaranya mampu dikenali dengan benar. Dengan kata lain metode yang digunakan memiliki tingkat akurasi hingga 97,10\% (Avianto, 2016).

Pengertian penelitian dalam akademik yaitu digunakan untuk mengacu 
pada aktivitas yang rajin dan penyelidikan sistematis atau investigasi di suatu daerah, dengan tujuan menemukan atau merevisi fakta, teori, aplikasi dan tujuannya adalah untuk menemukan dan menyebarkan pengetahuan baru (Berndtssom, Hansson, Olsson, \& Lundell, 2008).

Ada empat metode penelitian yang umum digunakan yaitu tindakan penelitian, eksperimen, studi kasus dan survey (Dawson, 2009). Dalam konteks penelitian, metode yang dilakukan mengacu kepada pemecahan masalah yang meliputi mengumpulkan data, merumuskan hipotesis atau proposisi, pengujian hipotesis, menafsirkan hasil, dan kesimpulan (Berndtssom, Hansson, Olsson, \& Lundell, 2008).

Dalam penelitian ini dilakukan beberapa langkah yang dilakukan dalam proses penelitian.

\section{Instrumen Penelitian}

Pada tahap ini dijelaskan fitur yang apa saja yang terdapat dalam dataset dan menjelaskan dataset tersebut diklasifikasikan termasuk jenis klasifikasi Binominal (diklasifikasikan menjadi 2 kategori) atau Polynominal (diklasifikasikan kedalam 3 kategori atau lebih dari 3).

\section{Metode Pengumpulan Data}

Pada tahap ini ditentukan data yang akan diproses. Mencari data yang tersedia, memperoleh data tambahan yang dibutuhkan, mengintegrasikan semua data ke dalam data set, termasuk variabel yang diperlukan dalam proses.

Data Kardiotokografi diperoleh dari University of Porto, Portugal dalam eksperimen ini digunakan data Campos et al. Data yang digunakan untuk training dan testing merupakan data sekunder yang diklasifikasikan sebanyak 2126 janin cardiotocograms (CTGs) diolah secara otomatis dan fitur diagnostik masing-masing telah diukur. CTGs juga diklasifikasikan oleh tiga ahli obstetricians dan label klasifikasi diberikan ke masing-masing klasifikasi. Data Kardiotokografi dapat diunggal melalui halaman website :

(http://archive.ics.uci.edu/ml/datasets/Cardioto cography).

\section{Metode Analisis Data}

Pada tahap ini data dianalisis, dikelompokan variabel mana yang berhubungan dengan satu sama lainnya. Setelah data dianalisis lalu diterapkan model-model yang sesuai dengan jenis data. Pembagian data kedalam data latihan (training data) dan data uji (testing data) juga diperlukan untuk pembuatan model.

Pada tahap ini, dibutuhkan eksplorasi dari datasets yang disediakan. Diketahui bahwa tujuan utama yang ingin dicapai adalah untuk mengetahui hasil klasifikasi terbaik dataset Kardiotokografi. Dibutuhkan metode yang diusulkan dan evaluasi dan validasi untuk mengetahui efektifitas dari klasifikasi dataset Kardiotokografi.

A. Metode yang Diusulkan

Dalam penelitian ini akan memilih dan menerapkan teknik yang tepat untuk klasifikasi dataset Kardiotokografi. Tahap pertama dalam penelitian ini adalah membagi dataset Kardiotokografi menjadi 10 bagian dengan menggunakan cross validation, dimana semua bagian dataset akan menjadi data training dan data testing. Setelah data tersebut terbagi menjadi data training dan testing langkah selanjutnya adalah dilakukan diklasifikasi menggunakan algoritma Neural network. Hasil dari klasifikasi akan diukur dengan nilai akurasi. Desain penelitian dapat dilihat pada gambar III.1.

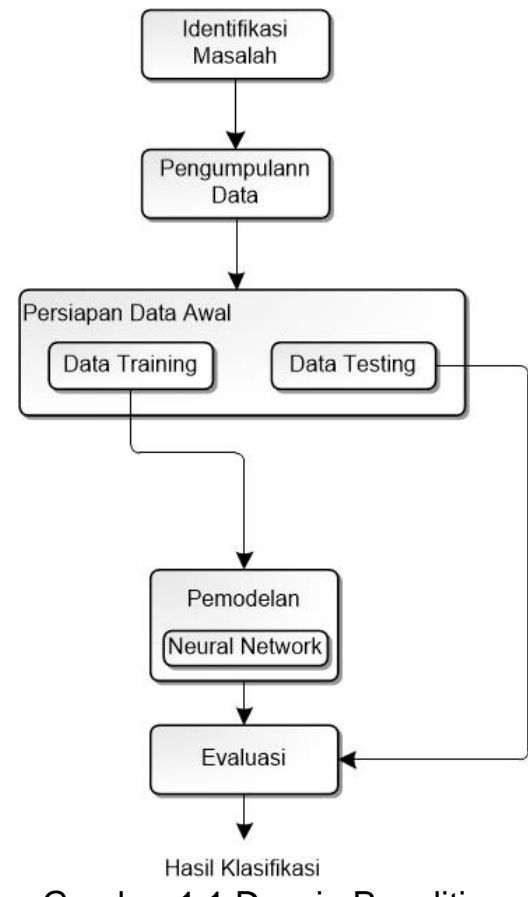

Gambar 1.1 Desain Penelitian

B. Evaluasi Dan Validasi

Pada tahap ini dilakukan evaluasi menggunakan tabel confusion matrix untuk melakukan pengukuran kinerja algoritma pada model algoritma klasifikasi. Kinerja yang diukur adalah Accuracy. Validasi yang dilakukan dengan menggunakan 10-fold cross validation dimana dataset akan dibagi dalam 
dua segmen yaitu, data training dan data testing menjadi 10 bagian. Kinerja model akan dibandingkan dengan algoritma Neural network. Untuk membandingkan hasil tersebut diukur menggunakan Accuracy sehingga hasil yang didapat lebih akurat.

\section{Hasil dan Pembahasan}

Pada tahap ini ditampilkan hasil eksperimen klasifikasi dataset Kardiotokografi menggunakan algoritma Neural network. Tahap awal dilakukan identifikasi dataset, diketahui bahwa jumlah dataset Kardiotokografi sebanyak 2126 record, tahap selanjutnya dilakukan pemisahan data training dan testing menggunakan 10 fold cross validation pembagian data menjadi, data training $90 \%$ dan data testing $10 \%$. Data training untuk dijadikan model dan data testing untuk mendapatkan akurasi dengan sebaran data pada tabel IV.1.

Tabel IV.1 Sebaran Dataset Kardiotokografi

\begin{tabular}{|l|l|c|c|c|}
\hline NO & $\begin{array}{l}\text { Jenis } \\
\text { Klasifikasi }\end{array}$ & $\begin{array}{l}\text { Jumlah } \\
\text { Record } \\
\text { Dataset }\end{array}$ & $\begin{array}{l}\text { Data } \\
\text { Training }\end{array}$ & $\begin{array}{l}\text { Data } \\
\text { Testing }\end{array}$ \\
\hline $\mathbf{1}$ & Normal & 1655 & 1490 & 165 \\
\hline $\mathbf{2}$ & Suspect & 295 & 266 & 29 \\
\hline $\mathbf{3}$ & Pathologic & 176 & 158 & 18 \\
\hline \multicolumn{2}{r}{ Jumlah } & 2126 & 1914 & 212 \\
\hline
\end{tabular}

Klasifikasi dataset Kardiotokografi diuraikan ke dalam 3 kelas dengan kelas Normal, kelas Suspect, dan kelas Pathologic dengan atribut sebanyak 36 dengan penjelasan pada tabel IV.2, dengan atribut sebanyak 36 dan Output sebanyak 3. Model algoritma Neural Netwrok dalam penelitian ini menggunakan satu buah lapisan input yang terdiri dari 37 neuron (36 neuron adalah atribut yang digunakan sebagai predictor dan satu neuron bias), satu buah lapisan tersembunyi yang terdiri dari 21 buah neuron, dan tiga buah lapisan Output yang merupakan hasil klasifikasi, model dari algoritma Neural network. Hasil akurasi klasifikasi algoritma Neural network dengan nilai akurasi sebesar 99.15\%. Pada tabel IV.3 dijelaskan nilai dari akurasi yang dihasilkan oleh algoritma Neural network yang akan diajukan sebagai rujukan model yang dapat diimplementasikan dengan baik untuk dilakukan penelitian selanjutnya. Keterangan yang diberikan pada tabel tersebut diantaranya, pred 1, pred 2, dan pred 3 merupakan prediksi dari dataset dikategorikan menjadi 3 kelas yaitu Pred $1=$ Normal, Pred $2=$ Suspect, Pred $3=$ Pathologic. Sedangkan untuk True 1, True 2,
True 3, hasil komparasi antara dataset testing dengan dataset training, dimana tingkat akurasi yang diberikan dari masing-masing prediksi maupun hasil akurasi prediksi dari keseluruhan dataset.

Tabel I.2 Hasil Klasifikasi Algoritma Neural network

\begin{tabular}{|l|c|c|c|l|}
\hline & $\begin{array}{l}\text { true } \\
\mathbf{2}\end{array}$ & true 1 & true 3 & $\begin{array}{l}\text { class } \\
\text { precisio } \\
\text { n }\end{array}$ \\
\hline pred. 2 & 283 & 4 & 1 & $98.26 \%$ \\
\hline pred. 1 & 10 & 1651 & 1 & $99.34 \%$ \\
\hline pred. 3 & 2 & 0 & 174 & $98.86 \%$ \\
\hline class & 95. & 99.76 & 98.86 & \\
recall & 93 & $\%$ & $\%$ & \\
& $\%$ & & & \\
\hline
\end{tabular}

Ket

Pred $1=$ Normal

Pred 2 = Suspect

Pred $3=$ Pathologic

Komparasi hasil eksperimen yang telah dilakukan meliputi klasifikasi menggunakan algoritma Neural network, K-NN, Naïve Bayes, C.45, Random Forest untuk klasifikasi menggunakan Neural network dengan hasil pada tabel 7 .

Tabel I.3 Tabel Algoritma Klasifikasi Kardiotokografi

\begin{tabular}{|c|c|c|c|}
\hline No & Algoritma & Akurasi & Ket \\
\hline $\mathbf{1}$ & k-NN & $81.28 \%$ & Default \\
\hline $\mathbf{2}$ & $\begin{array}{c}\text { Naïve } \\
\text { Bayes }\end{array}$ & $97.32 \%$ & Default \\
\hline $\mathbf{3}$ & C.45 & $98.45 \%$ & Default \\
\hline $\mathbf{4}$ & $\begin{array}{c}\text { Random } \\
\text { Forest }\end{array}$ & $86.03 \%$ & Default \\
\hline $\mathbf{5}$ & $\begin{array}{c}\text { Neural } \\
\text { Nework }\end{array}$ & $99.11 \%$ & Default \\
\hline $\mathbf{6}$ & $\begin{array}{c}\text { Neural } \\
\text { Nework }\end{array}$ & $99.15 \%$ & $\begin{array}{l}\text { learning rate } \\
\text { 0,5 dan } \\
\text { momentum } 0,5\end{array}$ \\
\hline
\end{tabular}

Pada tabel hasil komparasi klasifikasi terlihat bahwa klasifikasi algoritma Neural network dengan nilai Learning Rate 0,5 dan Momentum 0,5 dengan nilai akurasi 99.15\% lakurasi terlihat baik. Gambar IV.7 menjelaskan grafik perbandingan antara klasifikasi menggunakan algoritma Neural network, K-NN, Naïve Bayes, C.45, Random Forest untuk klasifikasi menggunakan Neural network. 


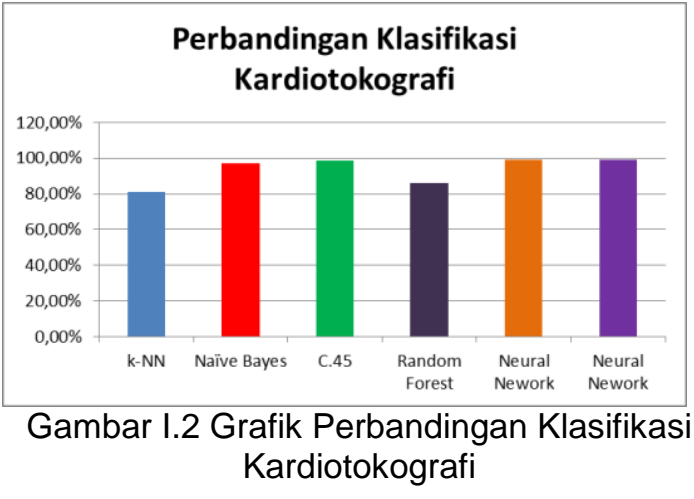

Implikasi Penelitian

Berdasarkan pengujian yang telah diperoleh pada dataset Kardiotokografi, maka diketahui bahwa algoritma Neural Network memiliki akurasi yang paling tinggi jika dibandingkan dengan algoritma klasifikasi lainnya.

Penelitian lebih lanjut dapat dilakukan dengan cara seperti berikut :

1. Hasil penelitian dapat membantu dan dapat diimplimentasikan untuk klasifikasi kelainan janin oleh ahli Kandungan.

2. Melakukan optimasi pamarameter dan atribut pada setiap algoritma klasifikasi untuk meningkatkan hasil akurasi.

\section{Kesimpulan}

Berdasarkan uraian yang telah dibahas pada bab-bab sebelumnya mengenai Klasifikasi dataset Kardiotokografi menggunakan algoritma Neural network, baik secara teoritis maupun penerapannya. Maka penulis dapat mengambil kesimpulan sebagai berikut :

1. Model klasifikasi algoritma Neural network dapat melakukan klasifikasi dataset kardiotokografi dengan baik, dibuktikan oleh nilai akurasi yang dihasilkan sebesar 99,15\% hal itu memperlihatkan bahwa klasifikasi kardiotokografi menggunakan algoritma neural network dapat diimplementasikan menggunakan aplikasi klasifikasi kardiotokografi dalam membantu pada saat melakukan klasifikasi.

2. Dengan adanya Aplikasl klasifikasi kardiotokografi diharapkan dapat membantu ahli kandungan dalam melakukan proses klasifikasi janin menggunakan dataset kardiotokografi. Dengan adanya aplikasi proses klasifikasi dapat dilihat dengan cepat. Klasifikasi janin dibagi menjadi 3 kelompok yaitu Normal, Suspect dan Pathologic.
Dengan demikian dari hasil pengujian model dapat disimpulkan bahwa klasifikasi kardiotokografi menggunakan algoritma neural network dapat dijadika rujukan untuk menganalisis klasifikasi kardiotokografi

\section{Saran}

Diketahui bahwa klasifikasi menggunakan algoritma neural network meiliki akurasi yang tinggi, namun untuk penelitian selanjutnya hal-hal berikut dapat dijadikan rujukan untuk meningkatkan akurasi dan efektivitas klasifikasi kardiotokografi diantaranya:

1. Aplikasi ini dapat menggunakan metode klasifikasi yang lainnya agar mendapatkan nilai Akurasi yang lebih tinggi dari hasil yang telah penulis lakukan.

2. Menggunakan metode optimasi parameter seperti Particle Swarm Optimimization, Backward Elimination, Forward Selection dan Genetic Algorithm untuk meningkatkan akurasi dari Klasifikasi Kardiotokografi.

3. Menggunakan optimasi bobot seperti Adaboost, Bagging dan Stacking untuk meningkatkan akurasi klasifikasi Kardiotokografi.

\section{Referensi}

Avianto, D. (2016). Pengenalan Pola Karakter Plat Nomor Kendaraan Menggunakan Algoritma Momentum Backpropagation Neural Network. Jurnal Informatika, 1199-1209.

Berndtssom, M., Hansson, J., Olsson, B., \& Lundell, B. (2008). A Guide For Students In Computer Science And Information Systems. London: Springer.

Dawson, C. (2009). Projects In Computing And Information System A Student's Guide. England: Addison-Wesley.

Dinkes Sulut. (2013). Laporan Tahunan Program KIA Sulut. Manado.

Endjun, J. J., \& Affandi, B. (2013). KARDIOTOKOGRAFI (KTG). Jakarta.

Karegowda, A., Manjunath, A., \& Jayaram, M. (2011). Application Of Genetic Algorithm Optimized Neural Network Connection Weights For Medical Diagnosis Of Pima Indians Diabetes. International Journal on Soft Computing ( IJSC ), 15-23. 
Kusumawati, D., Winarno, W. W., \& Arief, M. R. (2015). PREDIKSI KELULUSAN MAHASISWA MENGGUNAKAN METODE NEURAL NETWORK DAN PARTICLE SWARM OPTIMIZATION. Seminar Nasional Teknologi Informasi dan Multimedia 2015, 37-42.

Mohammad, B. (2012). Prediksi Hasil Pemilu Legislatif Dki Jakarta Dengan Metode Neural Network Berbasis Particle Swarm Optimization. Jakarta: Thesis.

Sahin, H., \& Subasi, A. (2015). Classification of the cardiotocogram data for anticipation of fetal risksusing machine learning techniques. Applied Soft Computing, 231-238.

Sakur, S., \& Tjandrasa, H. (2016). Klasifikasi Aktivitas Mental Berdasarkan Data Eeg Menggunakan Metode Hibridneural Network Dan Fuzzy Particle Swarm Optimization Dengan Crossmutated Operation. Jurnal IImiah Teknologi Informasi, 44-62.

Santosa, B. (2007). Data Mining: Teknik Pemanfaatan Data untuk Keperluan Bisnis. Yogyakarta: Graha IImu.

Sari, Y., Marleny, F. D., Izzana, M., Ricardus , \& Lareno, B. (2015). Optimasi Conjugate Gradient Pada Backpropagation Neural Network untuk Deteksi Kualitas Daun Tembakau. Konferensi Nasional Sistem \& Informatika 2015, 396-401.

Setiyorini, T. (2015). Penerapan Metode Bagging untuk Mengurangi Data Noise pada Neural Network untuk Estimasi Kuat Tekan Beton. Journal of Intelligent Systems.

Soni, J., Ansari, U., Sharma, D., \& Soni, S. (2011). Predictive Data Mining for Medical Diagnosis: An Overview of Heart Disease Prediction. International Journal of Computer Applications, 44-48.

Yulianto, A. A., \& Fitriati, A. (2008). Sistem Informas iManajemen Edisi 10. Jakarta: Salmeba Empat. 